\title{
Háziorvosok és idősellátás egy kérdőíves kutatás tükrében
}

\author{
Tróbert Anett Mária - Széman Zsuzsanna dr.
}

Semmelweis Egyetem, Egészségügyi Közszolgálati Kar, Mentálhigiéné Intézet, Budapest

\begin{abstract}
A statisztikai adatok szerint az egészségben eltöltött évek száma nem növekszik az átlagéletkor kitolódásával arányosan. A tartós gondozási rendszerek az elöregedő társadalmakban egyre terheltebbek, fenntarthatóságuk szempontjából az egyik leglényegesebb kérdés a költséghatékony múködés és ehhez kötődően a szolgáltatások összehangolása. Az egészségügyi és szociális ellátórendszer jelenlegi szeparáltsága számos nehézséget indukál.

Az online kérdőíves kutatás célja egyfelől az idősellátásban igen fontos részt vállaló háziorvosok idős betegeikkel, azok hozzátartozóival és az idősgondozást végző szociális szakemberekkel való viszonyának felmérése volt, másfelől információgyưjtés az ellátórendszer orvosok által tapasztalt hiányosságairól, az idősellátás javításának lehetőségeiről háziorvosi szemmel. Az eredmények leíró statisztikai és tartalomelemzéssel kerültek kiértékelésre. Az országosan 5060 címre kiküldött kérdőívet összesen 145-en töltötték ki. A kitöltők számos javaslatot fogalmaztak meg az idősellátás javítására a szociális fejlesztés, a családi támogatás, az egészségügyi fejlesztés és a társadalmi összefogás kategóriáiban. A háziorvosok által megnevezett fejlesztendő területek az idősgondozásban szorosan kapcsolódnak egymáshoz: a szociális ellátás reformja támogatná az egészségügyi ellátórendszert, és fordítva. Az egészségügyi és szociális ellátórendszerek hatékonyabb múködése a családok terheit csökkentené, ugyanakkor elősegítené a családok gondozási folyamatban való aktívabb részvételét. A tudatos társadalmi, közösségi edukáció pedig olyan hosszú távú befektetés, melynek hatására erősödhet az időskorhoz való pozitív hozzáállás, az idősödés folyamatának értékközpontú szemlélete, ami az idősek sikeres társadalmi integrációjának egyik alapfeltétele.
\end{abstract}

Orv Hetil. 2018; 159(8): 312-319.

Kulcsszavak: tartós gondozás, idős betegek, háziorvosok, szociális szolgáltatások

\section{General practitioners and eldercare reflected in a survey by questionnaire}

According to statistical data, the number of healthy life years is not increasing in proportion with the longer average life expectancy. In the ageing societies, the long-term care systems are increasingly overburdened; cost-efficient operation and the related coordination of services is one of the key questions for their sustainability. The present separation of the health care and social care systems causes numerous difficulties. One aim of the online research by questionnaire was to survey the attitude of general practitioners - who play a very important part in care for the elderly - towards their elder patients, the patients' family members, and social workers providing eldercare. The other aim was to gather information on shortcomings experienced by doctors in the care system and on what possibilities general practitioners see for the improvement of eldercare. Semi-structured questionnaires were applied and analysed by descriptive and content methodology. The questionnaires were sent out to 5060 addresses around the country: a total of 145 were returned filled in. The respondents made many recommendations for the improvement of eldercare in the categories of development of social services, family support, development of health services, and societal cooperation. The areas in need of development named by the general practitioners are closely interrelated: the reform of social care would support the health care system and vice versa. More effective operation of the health and social care systems would ease the burdens of families, and at the same time encourage more active participation of families in the care process. And the systematic education of society and communities is a long-term investment that would strengthen a positive attitude towards old age and a value-oriented view of the ageing process that is one of the basic conditions for successful social integration of the elderly.

Keywords: long-term care, elderly patients, general practitioners, social services

Tróbert AM, Széman Zs. [General practitioners and eldercare reflected in a survey by questionnaire.] Orv Hetil. 2018; 159(8): 312-319.

(Beérkezett: 2017. október 9.; elfogadva: 2017. október 31.) 
A társadalmak elöregedése miatt korunk egyik legnagyobb szociális-egészségügyi kihívása a szükségletekhez igazodó és minőségi idősgondozás biztosítása. Az otthoni tartós gondozás megvalósításában a házi segítségnyújtást biztosító szociális ellátórendszer mellett kiemelkedő szerepük van a háziorvosoknak. A „2015. évi CXXIII. törvény az egészségügyi alapellátásról” szerint biztosítani kell a hosszú távú személyes kapcsolaton alapuló folyamatos ellátást a beteg nemétől, korától és betegsége természetétôl függetlenül, ami szükség esetén magában foglalja a beteg otthonában történő ellátását, házi ápolását ${ }^{1}$ [1]. A krónikus betegséggel élő, önellátásra csak részben vagy egyáltalán nem képes idősek háziorvosi ellátása rendszeres, időigényes, megterhelő feladat. Az egészségmegőrzést előmozdító, aktív idősödést is támogató prevenciós munka egyre égetőbb lenne, jelenlegi feltételei azonban a hazai háziorvosi rendszerben rossznak mondhatóak: az adminisztratív terhek a munkaidő jó részét felemésztik, az orvosoknak prevencióra gyakorlatilag nincs idejük. További, ehhez kapcsolódó nehézség, hogy a fejkvótarendszer létszám-maximalizáláshoz vezet a minőségi munka rovására [2]. Az időigényes, nagy odafigyelést kívánó otthoni ellátást tekintve komoly problémát jelenthet a háziorvosok magas fokú megterheltsége is. Egy 2007-es, a háziorvosok kiégését vizsgáló hazai kutatás $(\mathrm{N}=496)$ eredményei szerint a vizsgált mintában a magas fokú emocionális kimerülés prevalenciája mintegy 30, a magas fokú deperszonalizáció prevalenciája 40-60, a magas fokú teljesítménycsökkenés pedig közel 100\%-os volt [3]. A háziorvosok tehermentesítése, a minőségi munka és a prevenció egyik jól múködő mintáját mutatják más országokban a multidiszciplináris praxisok. A kétszemélyes, háziorvos-asszisztens rendszer alternatívájaként a multidiszciplináris teameket integráló praxisközösségek múködtetése hazánkban is kívánatos lenne [2]. A szektoron belüli és a szektorok közötti együttmúködés akkor lehet hatékony, ha különböző szolgáltatások összhangjával komplex ellátást valósít meg [4]. A szerteágazó ismereteket és sokféle szakértelmet megkívánó tartós idősgondozás területén az egészségügyi és szociális ellátórendszereket összekapcsoló integrált gondozás különösen fontos lenne. Jelenleg szinte teljesen szeparáltan múködik a két szektor. Bár a 4/2000. (II. 25.) EüM rendelet előírja, hogy a háziorvosok feladata a szociális ellátórendszerrel, illetve az otthoni szakápolást nyújtó szolgáltatókkal való együttmúködés is ${ }^{2}$ [5], a szociális szakemberek és a beteget gondozó családtagok tapasztalatai szerint ennek megvalósulása gyakran akadályokba ütközik. A magyar részvétellel zajlott MoPAct

\footnotetext{
2. $\$(2) b d$ ) és $c$ ) pont.

2 Vö. 2. számú melléklet 10 .
}

nemzetközi kutatás ${ }^{3}$ szakértői és fókuszcsoportos interjúi alapján a tartós idősgondozás egyik legnagyobb problémája a szolgáltatások integrációjának és koordinációjának hiánya: a szociális és egészségügyi rendszerek közötti kapcsolat- és együttmúködés-hiány gyakran okoz „párhuzamos”, „dupla” ellátást, vagy ellenkezőleg, ellátatlanságot [6]. A Magyarországon készült interjúk eredményei szerint a háziorvosokkal való kapcsolat és együttmúködés hiánya ezenfelül a szociális szakemberek munkáját is számos esetben megnehezíti. Egy szintén magyar részvétellel zajlott nemzetközi kutatásban (QuInnE) is kiemelték a házi gondozásban dolgozó szakemberek a szociális és az egészségügyi ellátás kapcsolatának és összehangolásának hiányát, valamint az együttmúködés nehézségeit - nemcsak a háziorvosok, hanem a szakorvosok vonatkozásában is ${ }^{4}$ [7]. Ez az ápolásban részt vevő családtagoknak is problémát jelent, hiszen gyakran közvetítő szerepbe kényszerülnek a két rendszer között [8]. A MoPAct-kutatás keretében hozzátartozókkal készült interjúkban emellett hangsúlyos nehézség az információhiány is: a kórházi ellátást követően a betegek és/vagy családtagjaik gyakran magukra maradnak a problémákkal, és nem kapnak megfelelő tájékoztatást az elérhető szociális szolgáltatásokról sem a háziorvostól, sem a kórházaktól ${ }^{5}$ [9]. Az alapellátás megújításának egyik legfontosabb eleme lenne a partneri viszonyt előmozdító szemléletváltás, hogy a beteg ne csupán passzív elfogadója, hanem aktív résztvevője, formálója is legyen az ellátásnak [4]. Ez a gondozásra szoruló idősek tekintetében egyben a hozzátartozók aktív bevonását, partnernek tekintését is megkívánná az ápolási-gondozási folyamatban.

Az alapellátás minőségének javítása érdekében a háziorvosi munkát 2009 óta már hazánkban is ún. minőségi indikátorokkal mérik, ezek jó része azonban a háziorvos által kevéssé befolyásolható mutatókon alapszik, a betegek elégedettségére pedig egyáltalán nem tér ki [10]. Bár az indikátorrendszer ennek ellenére nagyrészt pozitív fogadtatásra lelt a háziorvosok körében, motiváló hatása nem jelentős, mivel nem társul hozzá kellő mértékű anyagi ösztönzés [11]. Az idős betegek otthoni gondozását biztosító szociális ellátás szakmai színvonalának mérését tekintve is számos nehézség fogalmazható meg. Bizonyos intézmények, szolgálatok „minőségbiztosítot-

\footnotetext{
${ }^{3}$ A hosszú távú idősellátást megvalósító tartós gondozási rendszerek az EU számos országában megújításra szorulnak. Az aktív idősödés szegmenseit vizsgáló MoPAct-projekt (2014-2017) WP8-munkacsoportjának egyik célja ezért az európai tartós gondozással összefüggő szociális innováció lehetőségeinek feltárása volt. Ennek keretében sor került a kutatásban részt vevő országokban elérhető gondozási szolgáltatások vizsgálatára is. A projektet finanszírozta: European Commission's Seventh Framework Programme FP7-SSH-2012-1/No 320333, http://mopact.group.shef.ac.uk/

4 A QuInnE - 'Quality of jobs and Innovation generated Employment outcomes’ projekt, No. 649497 (2015-2018) - az innovációk és a munka minősé gének kapcsolatát vizsgálja több szektorban. A projekt finanszírozója: Horizon 2020 Framework Programme of the European Commission, http://bryder.nu/ ${ }^{5}$ Az egyik interjúalany például egy rádiómúsor kapcsán lett figyelmes arra, hogy édesanyja ápolása miatt anyagi támogatásban részesülhet.
} 
1. táblázat |A kérdőívet kitöltő nők és férfiak kor szerinti megoszlása

\begin{tabular}{|c|c|c|c|c|c|c|c|c|c|c|c|c|c|c|}
\hline \multirow{3}{*}{$\begin{array}{l}\text { Nem } \\
\text { Férfi }\end{array}$} & \multicolumn{12}{|c|}{ Életkor } & \multirow{2}{*}{\multicolumn{2}{|c|}{ Összesen }} \\
\hline & \multicolumn{2}{|c|}{$35-44$} & \multicolumn{2}{|c|}{$45-54$} & \multicolumn{2}{|c|}{$55-64$} & \multicolumn{2}{|c|}{$65-69$} & \multicolumn{2}{|c|}{$70-74$} & \multicolumn{2}{|c|}{$\geq 75$} & & \\
\hline & 7 & $13,2 \%$ & 5 & $9,4 \%$ & 24 & $45,3 \%$ & 7 & $13,2 \%$ & 9 & $17,0 \%$ & 1 & $1,9 \%$ & 53 & $100 \%$ \\
\hline Nó & 9 & $9,8 \%$ & 28 & $30,4 \%$ & 36 & $39,1 \%$ & 12 & $13,0 \%$ & 6 & $6,5 \%$ & 1 & $1,1 \%$ & 92 & $100 \%$ \\
\hline Összesen & 16 & $11,0 \%$ & 33 & $22,8 \%$ & 60 & $41,4 \%$ & 19 & $13,1 \%$ & 15 & $10,3 \%$ & 2 & $1,4 \%$ & 145 & $100 \%$ \\
\hline
\end{tabular}

tak", egységes minőségbiztosítási rendszer azonban a szociális szférában nincs. Kialakítását megnehezíti, hogy az ellátásban igen hangsúlyos emberi tényezők nagyon nehezen mérhetők, valamint hogy a magasabb minőség biztosítása jelentős pénzügyi forrásokat kívánó szakmai és eszközfejlesztést is igényelne [12]. Az idősellátás minőségét tekintve súlyos probléma, hogy bár az idősgondozás az ápolási igények és követelmények növekedésével „medikalizálódik”, ezzel párhuzamosan az egészségügyi szolgáltatások elérhetősége nem növekszik, hanem éppen azok redukciója figyelhető meg [13]. Mivel a gondozási szükségleteket az ellátórendszerek számos esetben nem tudják lefedni, szükség van bizonyos gondozási feladatok egyéb úton való biztosítására. Az informális, vagyis az egészségügyi és szociális ellátórendszer keretein kívül igénybe vett, nem finanszírozott gondozást fóként családtagok biztosítják. Mivel a kutatások szerint a gondozási feladat a családtagok súlyos megterheltségével és egészségkárosodásával járhat, egyre inkább szükségessé válik a gondozók életminőségének mérése, javítása is [14].

A minőségi idősgondozás megvalósítása számos kérdést vet fel nem pusztán a szociális és egészségügyi ellátórendszerek szakmaisága és együttmúködése, hanem a családok és az idősek szempontjából is. A háziorvosokkal készült kérdőíves kutatásunk célja az volt, hogy felmérjük, hogyan élik meg a szociális ellátórendszerrel, valamint a rendszeres gondozásra szoruló idős pácienseikkel és hozzátartozóikkal való viszonyt, milyen tapasztalataik vannak az idósellátással kapcsolatosan, és milyen javaslataik vannak az ellátás javítására. A háziorvosokkal mindeddig nem készült felmérés ebben a témában.

\section{Módszer}

Az online kérdőívet az Országos Tisztiorvosi Hivatal Alapellátási Főosztályának közremúködésével országosan 5060 háziorvos kapta meg e-mailen, két alkalommal. Kétezer-tizenhat augusztusában 924, 2016 októberében pedig 718 olvasás volt regisztrálható. A levelet megnyitók közül mindösszesen 145-en töltötték ki a kérdőívet 2016. augusztus 8. és október 10. között.

A kérdőív témakörei: a válaszadók neme, kora, a háziorvosi praxis helye (településtípus); a 65 év feletti, önellátásra csak részben vagy egyáltalán nem képes, rendszeres orvosi konzultációt igénylő páciensek száma; az otthonukban rendszeresen látogatott idős betegek száma; a kapcsolat minősége az idős betegekkel, a kapcsolat minősége a hozzátartozókkal, a hozzátartozókkal való kapcsolat hiányának okai, a szociális ellátórendszerrel való kapcsolat; javaslatok az idősellátás javítására.

\section{Eredmények}

\section{A válaszadók neme, kora}

A 145 kitöltő háziorvos közül 53 férfi (37\%), 92 nő (63\%). A kitöltők közel kétharmada (64\%-a) 45-64 éves. A férfiaknál a legnépesebb korosztály az 55-64 éveseké: ebből való a férfi válaszadók $45 \%$-a, a többi kategóriában ennél jóval kisebb arányban képviseltetik magukat. A nők esetében a leginkább meghatározó korosztály a 45-64 éveseké, a női válaszadók közel 70\%-a ebbe tartozik ( 1 . táblázat).

\section{A kitöltők praxisainak megoszlása}

Valamennyi megye területéről érkeztek vissza kérdőívek, a részvételi arány azonban igen változó. A kérdőívet kitöltők közül a legtöbben Pest megyében praktizálnak:

2. táblázat |A kitöltók praxisainak településtípus szerinti megoszlása

\begin{tabular}{lcccccc}
\hline & \multicolumn{4}{c}{ Milyen típusú településen praktizál? } & Összesen \\
\cline { 2 - 5 } & Főváros & $\begin{array}{c}\text { Megye- } \\
\text { székhely }\end{array}$ & Város & Falu & Tanyavilág n & \\
\hline $\begin{array}{l}\text { A praxis } \\
\text { helye }\end{array}$ & 19 & 33 & 43 & 51 & 3 & 149 \\
\hline $\begin{array}{l}\text { Százalé- } \\
\text { kos arány }\end{array}$ & $12,8 \%$ & $22,1 \%$ & $28,9 \%$ & $34,2 \%$ & $2 \%$ & $100 \%$ \\
\hline
\end{tabular}

3. táblázat A rendszeres orvosi konzultációt igénylő, önellátásra csak részben vagy egyáltalán nem képes, 65 év feletti páciensek száma a háziorvosi válaszok alapján

\begin{tabular}{lc}
\hline $\begin{array}{l}\text { A } 65 \text { év feletti, önellátásra részben/egyáltalán nem képes, } \\
\text { rendszeres konzultációt igénylő páciensek száma }\end{array}$ & $\begin{array}{c}\text { A válaszok } \\
\text { száma }\end{array}$ \\
\hline 10 alatt & $11(7,6 \%)$ \\
$10-20$ & $32(22,1 \%)$ \\
$21-30$ & $27(18,6 \%)$ \\
$31-40$ & $22(15,2 \%)$ \\
$41-50$ & $12(8,3 \%)$ \\
$51-100$ & $26(17,9 \%)$ \\
100 felett & $15(10,3 \%)$ \\
\hline Összes válasz & $145(100 \%)$ \\
\hline
\end{tabular}


A 65 év feletti, önellátásra részben/egyáltalán nem képes, rendszeres konzultációt igénylő páciensek száma településtípus szerint, a háziorvosi válaszok alapján

\begin{tabular}{|c|c|c|c|c|c|}
\hline $\begin{array}{l}\text { A } 65 \text { év feletti, önellátásra részben/ } \\
\text { egyáltalán nem képes, rendszeres } \\
\text { konzultációt igénylő páciensek száma }\end{array}$ & Fôváros & Megyeszékhely & Város & Falu & Tanyavilág \\
\hline 10 alatt & $0(0 \%)$ & $2(6,1 \%)$ & $3(7,0 \%)$ & $6(11,8 \%)$ & $1(33,3 \%)$ \\
\hline $10-20$ & $3(15,8 \%)$ & $9(27,3 \%)$ & $12(27,9 \%)$ & $9(17,6 \%)$ & $0(0,0 \%)$ \\
\hline $21-30$ & $4(21,1 \%)$ & $10(30,3 \%)$ & $7(16,3 \%)$ & $6(11,8 \%)$ & $0(0,0 \%)$ \\
\hline $31-40$ & $2(10,5 \%)$ & $4(12,1 \%)$ & $6(14,0 \%)$ & $9(17,6 \%)$ & $2(66,7 \%)$ \\
\hline $41-50$ & $2(10,5 \%)$ & $1(3,0 \%)$ & $3(7,0 \%)$ & $6(11,8 \%)$ & $0(0,0 \%)$ \\
\hline $51-100$ & $6(31,6 \%)$ & $3(9,1 \%)$ & $7(16,3 \%)$ & $11(21,6 \%)$ & $0(0,0 \%)$ \\
\hline 100 felett & $2(10,5 \%)$ & $4(12,1 \%)$ & $5(11,6 \%)$ & $4(7,8 \%)$ & $0(0,0 \%)$ \\
\hline Összes válasz & $19(100 \%)$ & $33(100 \%)$ & $43(100 \%)$ & $51(100 \%)$ & $3(100 \%)$ \\
\hline
\end{tabular}

32 kérdőív érkezett vissza innen - ez a válaszadók 22\% át jelenti. A következő legmagasabb részvétel Borsod-Abaúj-Zemplén megyére jellemző, ahonnan 16-an (a válaszok 11\%-a) töltöttek ki kérdőívet. Elmondható, hogy abban a két megyében volt a legmagasabb a részvételi arány, ahol a praxisok száma a legnagyobb, de a részvétel ezen túl nem mutat összefüggést a megyékre jellemző praxisok számával.

A kitöltők közel kétharmada városban praktizáló orvos (64\%), és több mint egyharmaduk (34\%) dolgozik faluban. Négyen jelöltek meg két településtípust: a tanyavilágban dolgozó kitöltők közül ketten faluban is ellátnak szolgálatot. Egy kitöltő városban és faluban is dolgozik, egy pedig megyeszékhelyet és külön várost is megjelölt (2. táblázat).

\section{A rendszeres orvosi konzultációt igénylo", önellátásra csak részben vagy egyáltalán nem képes, 65 év feletti páciensek száma}

A válaszok alapján elmondható, hogy a mintában mindenféle páciensszám előfordul. Mivel az idősek ellátása nagy figyelmet, türelmet igénylö, gyakran megterheló feladat, fontos kiemelni, hogy az összes válaszadó 28\%ának esetében a rendszeres orvosi konzultációt igénylő, önellátásra csak részben vagy egyáltalán nem képes, 65 év feletti páciensek száma több, mint 50 (3. táblázat). A legtöbben 51-100 közötti beteget a fóvárosban látnak el: ez a budapesti kitöltők 31,6\%-ára jellemző, de a falvakban praktizálóknak is több mint egyötöde ebbe a kategóriába tartozik. A városokban praktizáló válaszadók több mint $10 \%$-a rendelkezik 100 -nál is több, önellátásra csak részben vagy egyáltalán nem képes, rendszeres konzultációt igénylő 65 év feletti pácienssel. Kiemelhetjük Budapest helyzetét - ahol összességében a válaszadók $42 \%$-a dolgozik - több mint 50 idős beteggel, de a megyeszékhelyeken, a városokban és a falvakban is magas, $21 \%$ feletti ez az arány (4. táblázat). A jelentős különbség oka feltételezhetően a fóvárosi praxisok magasabb lélekszáma.

\section{Az otthonukban rendszeresen látogatott 65 év feletti páciensek száma}

A mintában szereplők 68\%-a nem több, mint 20, viszont 11\%-a több mint 40 idős beteghez jár rendszeresen. A válaszadók $5,5 \%$-a esetében ez több mint 50 beteget jelent, ami különösen nagy megterheltségre utal (5. táblázat). Településtípus szerinti bontásban kiemelkedő, hogy a fóvárosi válaszadóknak több mint egynegyede (26\%) látogat rendszeresen több mint 40 idős beteget, és ugyanennyien számoltak be 31-40 közötti beteg rendszeres látogatásáról. A többi településtípuson praktizálók döntő többsége 20 vagy annál kevesebb idős beteget látogat rendszeresen (6. táblázat).

5. táblázat $\mid$ A rendszeresen látogatott, 65 év feletti páciensek száma a háziorvosi válaszok alapján

\begin{tabular}{lc}
\hline $\begin{array}{l}\text { A rendszeresen látogatott, } \\
65 \text { év feletti páciensek száma }\end{array}$ & A válaszok száma \\
\hline 10 alatt & $50(34,5 \%)$ \\
$10-20$ & $49(33,8 \%)$ \\
$21-30$ & $19(13,1 \%)$ \\
$31-40$ & $11(7,6 \%)$ \\
$41-50$ & $8(5,5 \%)$ \\
50 felett & $8(5,5 \%)$ \\
\hline Osszes válasz & $145(100 \%)$ \\
\hline
\end{tabular}

\section{A háziorvosok idös páciensekkel és bozzátartozóikkal való kapcsolatának minósége}

A kérdésre válaszolók 74\%-a (142-ből 105 fó) jónak, 22\%-a (32 fó) inkább jónak, míg 3,4\%-a ( 5 fö) közepesnek mondja az idős páciensekkel való viszonyát. ${ }^{6}$ Valamennyi praxisban előfordul, hogy a háziorvosok rend-

${ }^{6}$ A válaszok nem mutatnak szignifikáns összefüggést a válaszadók nemével $(\lambda=$ $0,034 ; \mathrm{p}=0,177)$. 
A 65 év feletti, önellátásra csak részben vagy egyáltalán nem képes, rendszeresen látogatott páciensek száma településtípus szerint, a háziorvosi vála szok alapján

\begin{tabular}{|c|c|c|c|c|c|}
\hline $\begin{array}{l}\text { A } 65 \text { év feletti, önellátásra részben/ } \\
\text { egyáltalán nem képes, rendszeresen } \\
\text { látogatott páciensek száma }\end{array}$ & Főváros & Megyeszékhely & Város & Falu & Tanyavilág \\
\hline 10 alatt & $2(10,5 \%)$ & $15(45,5 \%)$ & $13(30,2 \%)$ & $20(39,2 \%)$ & $3(100,0 \%)$ \\
\hline $10-20$ & $5(26,3 \%)$ & $10(30,3 \%)$ & $21(48,8 \%)$ & $13(25,5 \%)$ & $0(0,0 \%)$ \\
\hline $21-30$ & $2(10,5 \%)$ & $5(15,2 \%)$ & $4(9,3 \%)$ & $9(17,6 \%)$ & $0(0,0 \%)$ \\
\hline $31-40$ & $5(26,3 \%)$ & $2(6,1 \%)$ & $2(4,7 \%)$ & $2(3,9 \%)$ & $0(0,0 \%)$ \\
\hline $41-50$ & $4(21,1 \%)$ & $0(0,0 \%)$ & $0(0,0 \%)$ & $4(7,8 \%)$ & $0(0,0 \%)$ \\
\hline 50 felett & $1(5,3 \%)$ & $1(3,0 \%)$ & $3(7,0 \%)$ & $3(5,9 \%)$ & $0(0,0 \%)$ \\
\hline Összes válasz & $19(100 \%)$ & 33 (100\%) & $43(100 \%)$ & $51(100 \%)$ & $3(100 \%)$ \\
\hline
\end{tabular}

szeres kapcsolatba kerülnek a hozzátartozókkal. A velük való viszonyt a válaszadók túlnyomó többsége, 85\% (123 fó) jónak, 15\% (22 fó) pedig inkább jónak jellemzi.

\section{A hozzátartozókkal való kapcsolat hiányának okai a háziorvosok szerint}

Amikor nem alakul ki rendszeres kapcsolat az idősek hozzátartozóival, a mintában szereplők ennek messze leggyakoribb okaként a családtagok érdeklödésének hiányát tartják - 77\% (111 fö) jelölte meg ezt a választ. Figyelemre méltó, hogy a kérdőív kitöltőinek 11 százaléka (16 fó) úgy véli, hogy csak sürgós vagy súlyos esetben kell tájékoztatnia az idősek családtagjait. ${ }^{7}$ A válaszadók igen kis hányada jelölte meg a kapcsolat akadályaként a család részéról tapasztalt bizalmatlanságot (6 fó), a hozzátartozókkal való kapcsolattartás érzelmileg megterhelo" voltát (4 fó), a velük megélt korábbi konfliktusokat (2 fó), illetve a hozzátartozókkal való közelebbi kapcsolat bármilyen okból történő kerïlését (2 fő). A háziorvosokra háruló munkateher ellenére nagyon kevés válaszadó (mindössze 4 fó) hivatkozott időhiányra.

Az „egyéb okok" ${ }^{\circ}$ mezóben a legtöbben ( 5 válaszadó) a távolságot említették: előfordul, hogy már akkor is nehéz kapcsolatot teremteni a hozzátartozóval, amikor az külön háztartásban lakik. Még nehezebb a találkozás, ha a hozzátartozó távol - esetleg külföldön - él. A problémamentesség (4 válaszadó) is oka lehet a kapcsolat hiányának. Stabil állapotú betegnél vagy azoknál a pácienseknél, akik támogató családdal rendelkeznek, a háziorvos kevésbé érzi szülkségét a hozzátartozókkal való kapcsolattartásnak. A családtagok megterbeltsége (3 válaszadó) fontos indok: mivel a hozzátartozók általában dolgoznak, nehezen szakítanak időt a találkozásra. Sú-

\footnotetext{
${ }^{7}$ A kategóriát a férfiak és a nók közül majdnem azonos arányban jelölték: 6 férfi (a férfi válaszadók 11,3\%-a) és 10 nő (a női válaszadók 10,8\%-a).

${ }^{8}$ A kapcsolat hiányának egyéb okai mezőben öt válaszadó külön kiemelte, hogy van kapcsolata a hozzátartozókkal, egy közülük úgy nyilatkozott, hogy „Minden kivel van rendszeres kapcsolatom”, egy másik, hogy „Falun a családok több generációjával van kapcsolatom”.
}

lyosabb ok, amikor a család tehernek érzi az idős beteget, „nyügnek tekintik, szabadulnának tőle”, „nem érdekli őket az idős rokon". Előfordul az is, hogy a páciensnek nincs hozzátartozója (3 válaszadó szerint). A szociális ellátásban részesülők esetében megtörténik, hogy a kapcsolatot csak a szociális szakemberekkel tartják (3 válaszadó). Olyan esetról is beszámoltak (2 válaszadó), hogy maga a beteg nem igényli, hogy a háziorvos kapcsolatba lépjen a hozzátartozóival.

\section{Kapcsolat a szociális ellátórendszerrel}

A mintában szükség esetén valamennyi háziorvos kapcsolatba lép a szociális ellátórendszerrel. Ez nem jelent aktív kapcsolatot minden olyan páciens esetében, amikor a gondozott idős beteg szociális gondozást (házi segítségnyújtást) is kap, az orvosok $86 \%$-a azonban vagy az esetek többségében, vagy minden esetben kapcsolatot tart a szociális szakemberekkel ${ }^{9}$ (7. táblázat).

7. táblázat $\mid$ Az esetek mekkora részében van kapcsolata az Ön által is gondozott idős betegnek segítséget nyújtó szociális szolgálattal?

\begin{tabular}{lcc}
\hline & $\begin{array}{c}\text { A válaszok } \\
\text { száma }\end{array}$ & $\begin{array}{c}\text { Százalékos } \\
\text { arány }\end{array}$ \\
\hline „Minden esetben van.” & 62 & $42,8 \%$ \\
„Az esetek többségében van.” & 62 & $42,8 \%$ \\
„Az esetek fele részében van.” & 13 & $9 \%$ \\
„Az esetek kisebb részében van.” & 8 & $5,5 \%$ \\
„Nincs ilyen kapcsolatom.” & 0 & $0 \%$ \\
\hline Összesen & 145 & $100 \%$ \\
\hline
\end{tabular}

A mintára vonatkozóan a településtípus tekintetében elmondható, hogy a falvakban és a városokban dolgozó orvosok körében sokkal gyakrabban fordul elő a „minden esetben” válasz, mint a megyeszékhelyen és a fö-

9 Az egyes válaszok gyakorisága nem mutat szignifikáns összefüggést a válaszadók nemével $(\lambda=0,066 ; \mathrm{p}=0,231)$. 
városban: míg a falvakban dolgozók 59\%-a (30 fó) és a városokban dolgozóknak az 51\%-a (22 fó), addig a fóvárosiaknak csak a 26\%-a (5 fó), a megyeszékhelyeken dolgozóknak pedig csupán a 18\%-a (6 fó) állítja, hogy amikor az idős páciens házi segítségnyújtásban is részesül, akkor minden esetben kapcsolatban van a szociális szakemberekkel is. A megyeszékhelyeken és a fóvárosban az „esetek többségében” válasz gyakoribb: a megyeszékhelyeken dolgozók 64\%-a (21 fó), a fóvárosban dolgozók 47\%-a (9 fö) jelölte meg ezt. A városokban és a falvakban ez az érték alacsonyabb, és csak kis különbséget mutat a két településtípus között (3\% - 15 fó, illetve 33\% - 17 fö).

A kérdőívet kitöltők 97\%-ának (141 fő) van konkrét tapasztalata arról, hogy a szociális szakemberek segítették háziorvosi munkáját.

Egy kivétellel valamennyi válaszadó (145-ből 144 fő) úgy nyilatkozott, hogy a szociális ellátórendszer múködéséról tájékoztatást tud nyújtani a betegeknek, illetve hozzátartozóiknak.

\section{Javaslatok az idősellátás javítására}

Arra a kérdésre, hogy milyen javaslatai lennének az idősellátás javítására, összesen 94 fő (a kitöltők 65\%-a) válaszolt. A leírt javaslatok négy fó kategóriába rendezhetők.

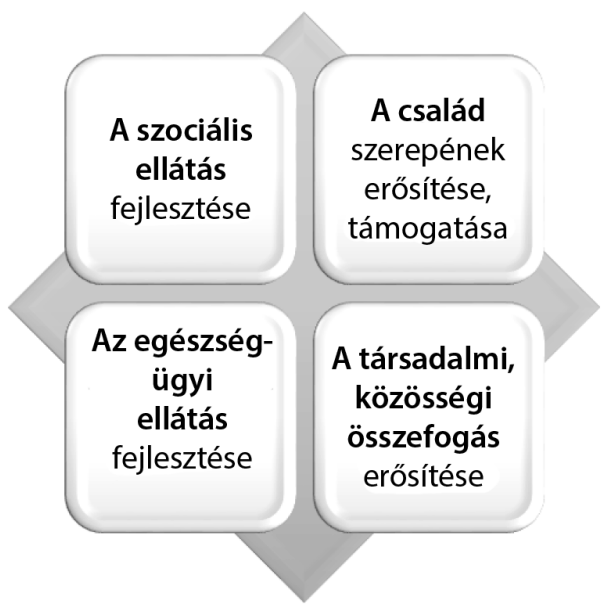

\begin{tabular}{l|l} 
1. ábra & $\begin{array}{l}\text { Az idősellátás fejlesztésének fő színterei a mintában részt vevő } \\
\text { háziorvosok javaslatai alapján }\end{array}$
\end{tabular}

1) A válaszokból kiderül, hogy a szociális ellátás fejlesztése égetóen fontos - erre összesen 105 javaslat érkezett (a javaslatok 71\%-a tartozik ebbe a csoportba).

A válaszok szerint a fejlesztés legfontosabb szegmense az ellátás kiterjesztése, ami jelenti a szociális ellátás, rendszer általános fejlesztését, a szervezeti egységek javítását, ezen belül pedig fóként a szolgáltatások/gondozói feladatok bővítését: több gondozási forma és lehetőség megvalósítását, különösen magányos betegeknél ${ }^{10}$.

${ }^{10} \mathrm{Az}$ egyik javaslat szerint fontos lenne például programok szervezése (foglalkoztatás) és az idősek odaszállításának megoldása.
A szolgáltatások kiterjesztéséhez tartozna az otthoni hospice-szolgáltatás elérhetővé tétele, de megjelent egy jelenleg teljesen hiányzó ellátási forma, a 24 órás otthoni ellátás biztosításának igénye is. A szolgáltatásbővítéshez szorosan kapcsolódik a kapacitásnövelés igénye - például a gondozási óraszám növelésével vagy a szociális gondozói hálózat bővítésével, szociális otthon létesítésével a kistelepüléseken is.

A professzionalitás, minöségi szakmai munka csoportjába tartozó ajánlások szerint nem pusztán több szociális szakember alkalmazása lenne szükséges, hanem szakképzett gondozók, több egészségügyi képzettségü gondozó, fizioterapeuta, gyógytornász is kellene. Lényeges lenne, hogy a szociális ellátásban eddig egyáltalán nem biztosított mentálhigiénés szakember vagy pszichológus, valamint dietetikus is elérhető legyen a rendszerben, ami teret adna az interdiszciplinaritás és a minőségi teammunka megvalósításának. A minőségi egyéni szakmai munka tekintetében fontos kérdés a személyes alkalmasság: ennek egyik alapfeltétele kellene, hogy legyen a válaszadók szerint az erkölcsi megfelelés és a titoktartás megkövetelése a gondozóktól, hiszen az idősek személyes segítése bizalmi állás, a gondozók bizalmas adatokhoz jutnak hozzá az idősekkel kapcsolatosan. A személyes alkalmasság megítéléséhez fontos lenne a háziorvos véleményének figyelembevétele is. A szakmaiság biztosításának lényeges eleme továbbá, hogy az idős beteget ellátó gondozó személye ne változzon, hiszen az idősek számára a személyes, bizalmi kapcsolat kiépítéséhez fontos a stabilitás.

Szintén nagy súllyal szerepel a rendszer fejlesztését érintő javaslatok között a gondozói státuszok számának növelése, a humánerőforrás-bövités igénye.

A rendszer finanszírozásának témakörében a több állami támogatás, a szociális rendszer jobb finanszírozása mellett fontos meglátás a dolgozók megfelelő, méltó bérezésének biztosítása, valamint a finanszírozott ellátás elérhetôvé tétele, ezzel együtt az ellátási díj csökkentése.

A javaslatok között megjelent a rendszer fejlesztéséhez kapcsolódó igen fontos alapfeltétel, az információáramlás és az együttmüködés elömozditása. Ennek egyik pillére lehetne a háziorvosi-kórházi-szociális ellátórendszer közötti informatikai összeköttetés - hogy látható és könynyebben követhető legyen, ki, mikor, milyen ápolásigondozási feladatot végzett az idős ember körül. Lényeges lenne a háziorvos erőteljesebb bevonása a gondozottal kapcsolatos döntésekbe, valamint szorosabb kapcsolat megvalósítása a gondozók és az önkormányzat között.

Az ellátás fejlesztésének egyik fontos eleme a folyamatosság - a további, jövőbeli fejlesztések megtervezése, vagyis a szükségletekhez igazodó ellátás biztosítása. Ennek érdekében a válaszadók szerint több visszajelzésre lenne szükség a hatékonyságról, szükségletekről. 
2) Igényként jelentkezett a családtagok szerepének tisztázása/erősítése a gondozási folyamatban, és a támogatásuk biztosítása - 27 javaslattal (az összes javaslat $18 \%$-a).

Ennek egyik legfontosabb feltétele a javaslatok alapján a megfeleló informálás: a családtagok felkészítése, képzése az idősgondozással, szociális ellátórendszerrel kapcsolatosan - azonban nemcsak a családtagok, hanem az idősek tájékoztatása is fontos lenne.

A válaszokból kitúnik, hogy a családok gondozási folyamatba való integrálása nélkülözhetetlen a fenntartható gondozásban: elvárásként fogalmazódott meg a kérdőívre válaszolók részérôl, hogy a családtagok vállaljanak többet az ellátásból. Ez viszont feltételezi a családtagok önállóságra nevelését (például ne mindent a rendszertól várjanak), de egyúttal aktív részvételük támogatását is. Az egyik válaszadó szerint a családtagok nem, vagy csak ritkán figyelnek idôs, esendő hozzátartozóikra. Ezért fontos lenne felelősségük növelése - például a hozzátartozó tartásáról született kormányrendeletet szigorúbb betartása. Egy másik háziorvos úgy nyilatkozott, hogy „kötelezôvé kellene tenni a szülőkről való gondoskodást". Ugyanakkor fontos kérdés a családok terhelhetôsége, hiszen általában dolgoznak, saját családdal rendelkeznek, és gyakran más településen élnek - tehát időbeli, anyagi és térbeli lehetőségeik is korlátozottak a gondozási folyamatban. Ez föként vidéken, kis településeken jelent problémát, ahol sok a magányos idős, ráadásul a település mérete miatt esetleg nem érhető el a napközi ellátás - ilyen esetben a szomszédok szerepe, támogatása különösen fontos.

A válaszok alapján megfogalmazhatjuk, hogy a hozzátartozók aktivitásnövelési igényével párhuzamosan lényeges lenne a beteget ápoló hozzátartozók megfeleló anyagi támogatása, ami magában foglalja a nagyobb anyagi segítség biztosítását a gondozásban - például az ápolási díj összegének növelését, illetve biztosítását akkor is, ha a gondozott nem fogyatékkal élő személy -, valamint az ápolási idő nyugdíjba való beszámítását. Fontos probléma, hogy 24 órás felügyeletet jelentős anyagi ráfordítás nélkül jelenleg csak a család tudna biztosítani, ez viszont számos esetben nem kivitelezhető.

A háziorvosok szerint a családok támogatásának alapeleme a tehermentesités megoldása: egyrészt idős beteget rendszeresen, átmenetileg fogadó intézmények fejlesztésével, másrészt a családtagok mentálhigiénés, pszichés támogatásának biztosításával. A lelki támogatás elősegítené a családtagok idős emberrel való pozitívabb viszonyát, ami az egész gondozási folyamatra kedvezően hatna.

Végül, de nem utolsósorban a család gondozási szerepével kapcsolatos javaslatok szerint a családok aktív részvétele elösegitésének feltétele a szakemberekkel, háziorvossal való kapcsolatuk erösitése, minőségének javitása.

3) A szociális ellátás fejlesztésének igényével párhuzamosan a javaslatokban megjelent a minöségi, folyamatosan elérhetó egészségïgyi ellátás biztositásának igénye a tartós gondozás rendszerében. A válaszadók erre vonatkozóan 14 javaslatot írtak, ami az összes javaslat $9,5 \%$-át jelenti.

A legfontosabb témacsoport ezen a területen az otthoni ápolás elōtérbe helyezése a folyamatosság biztosításával, hiszen az otthonápolás jelenleg limitált. Az egyik válaszadó szerint „jobb életminőséget lehetne elérni, ha nem lenne ez a korlát, és lenne megfelelő munkaerő". Ehhez fontos volna egyrészt az elérhetôség megkönnyítése, másrészt a gyakoribb és hosszabb ideig való ellátás biztosítása otthon. A háziorvos munkáját és a beteg otthoni ellátását elősegítené a segédeszközök könnyebb biztosítása is - jó lenne, ha nem kellene ehhez kórházi szakorvoshoz vinni a beteget, és a gyógyászati segédeszközöket a háziorvos is felírhatná. Az otthoni ápolás biztosításának feltétele lenne a megfeleló számú egészségügyi dolgozó alkalmazása is: több ápolónő, illetve több háziorvosi aszszisztens finanszírozása. ${ }^{11}$

Az ellátások elérhetöségéhez, az esélyegyenlöség biztositásához szükség lenne betegszállító jármúre, illetve a betegszállítás OEP-finanszírozására, valamint a gyógyszerek biztosítására akkor is, ha az idősnek/családnak nincs rá pénze.

Az otthoni ellátás preferenciájával párhuzamosan fontos az intézményi háttér megteremtése is: az idős krónikus betegeket ellátó intézmények fejlesztése.

\section{4) Társadalmi és közösségi összefogás}

Egy válaszadó kiemelte a társadalmi részvétel lényeges voltát a szociális háló hiányosságainak pótlásában, amihez meglátása szerint szükség lenne „a társadalom edukálására már kisgyermekkortól”.

\section{Megbeszélés és következtetések}

A minta nem tekinthető reprezentatívnak, az eredmények összesítése nyomán született megállapítások az adott mintára érvényesek. Az eredmények ${ }^{12}$ értelmezésekor figyelembe kell vennünk, hogy valószínúleg olyan háziorvosok nyitották meg a levelet és töltötték ki a kérdőívet, akik érdeklődnek az idősellátás témája iránt, és/ vagy fogékonyak az ellátással kapcsolatos problémákra így feltételezhetóen pozitív hozzáállással rendelkeznek az idősek, családtagjaik és a szociális ellátórendszer irányában is.

A kérdő́ivet kitöltő háziorvosok túlnyomó többsége jónak mondja a viszonyát mind az idős páciensekkel, mind pedig azok hozzátartozóival. A szociális ellátórendszerrel csaknem valamennyi válaszadó kapcsolatban áll, és szinte mindnyájan tapasztalták már, hogy a szociális szakemberek segítik a háziorvosi munkát. Az idősek ellátása terén az orvosok terheltsége a nagyobb lélekszámú praxisokban, fő́ként a fővárosban erősebb, de az ellá-

\footnotetext{
${ }^{11}$ Az egyik válaszadó praxisában jelenleg 2600 betegre két nővér jut.

${ }^{12}$ Az eredmények elemzése az SPSS PASW Statistics 18-as verziójának használatával történt.
} 
tandó idősek száma az egész mintában is magasnak mondható. A válaszadóknak az idősellátás javításával kapcsolatos meglátásai túlnyomórészt a szociális ellátórendszer fejlesztésére vonatkoznak. Ezt követően a legnagyobb csoportot a családtagok szerepével kapcsolatos tapasztalatok, igények képezik, de szintén kiemelkedó területnek mutatkozik a házi egészségügyi ellátás erősítésének szükségessége a tartós gondozás rendszerében. Bár csupán egy javaslatban jelent meg a társadalmi és közösségi összefogás jelentősége az idősellátás vonatkozásában, ez a szempont igen lényegesnek mondható, hiszen az erósebb szociális és kapcsolati háló azt a támogató, integráló szemléletet formálná, amely a betegség miatt sérülékennyé vált idősek és hozzátartozóik csoportjának marginalizációja ellen megtartó erőt jelenthet.

A háziorvosok által megnevezett, fejlesztendő területek az idősgondozásban szorosan kapcsolódnak egymáshoz: a szociális ellátás reformja támogatná az egészségügyi ellátórendszert, és fordítva. Az egészségügyi és szociális ellátórendszerek hatékonyabb múködése a családok terheit csökkentené, ugyanakkor elősegítené a családok gondozási folyamatban való aktívabb részvételét. A tudatos társadalmi, közösségi edukáció pedig olyan hosszú távú befektetés, amelynek hatására erősödhet az időskorhoz való pozitív hozzáállás, az idősödés folyamatának értékközpontú szemlélete, ami az idősek sikeres társadalmi integrációjának egyik alapfeltétele.

Anyagi támogatás: A kutatómunka és a cikk megírása anyagi támogatásban nem részesült.

Szerzői munkamegosztás: T. A. M.: A kutatás alapjául szolgáló kérdőív elkészítése, kiküldése, az eredmények összesítése, statisztikai elemzése, a kézirat megszövegezése. Sz. Zs.: Szakmai vezetés, a kézirat megszövegezése. A cikk végleges változatát mindkét szerző elolvasta és jóváhagyta.

Érdekeltségek: A szerzőknek nincsenek érdekeltségeik.

\section{Irodalom}

[1] Act No. CXXIII of 2015 on Primary Health Care. [2015. évi CXXIII. törvény az egészségügyi alapellátásról.] Available from: https://net.jogtar.hu/jr/gen/hjegy_doc.cgi?docid=al500123. tv [accessed: September 24, 2017]. [Hungarian]

[2] Rurik I. Problems and seeking for solutions in family medicine. [Gondok és útkeresés a háziorvoslásban.] Orv Hetil. 2009; 150: 1615-1622. [Hungarian]

[3] Ádám Sz, Torzsa P, Győrffy Zs, et al. Frequent occurance of level burnout among general practitioners and residents. [Gya- kori a magas fokú kiégés a háziorvosok és háziorvosi rezidensek körében.] Orv Hetil. 2009; 150: 317-323. [Hungarian]

[4] Dózsa Cs, Borbás F. Conceptual framework of integrated care and options for integration in primary care. [Az integrált ellátás koncepcionális keretrendszere és az integráció lehetôségei az alapellátásban.] Orv Hetil. 2015; 156: 881-887. [Hungarian]

[5] Regulation No. 4/2000. (II. 25.) of the Ministry of Health on the Activity of General Practitioners, Pediatricians and Dentists in Primary Care. [4/2000. (II. 25.) EüM rendelet a háziorvosi, házi gyermekorvosi és fogorvosi tevékenységről.] Available from: https://net.jogtar.hu/jr/gen/hjegy_doc.cgi?docid=a0000004. eum [accessed: September 24, 2017]. [Hungarian]

[6] Schulmann $\mathrm{K}$, Leichsenring $\mathrm{K}$, et al. A qualitative inventory of the key drivers of social innovation in social support and long term care (QUALIND), Final Report. Vienna, 2015; p. 28. Available from: http://mopact.group.shef.ac.uk/wp-content/ uploads /2013/10/D8.3-A-qualitative-inventory-of-the-keydrivers.pdf [accessed: September 24, 2017].

[7] Tróbert AM, Makó Cs, Illésy M. Poor job quality as a hindrance for innovation. Case study in the Hungarian old age care sector. QuInnE, Manuscript. Institute of Sociology - Centre for Social Sciences, Hungarian Academy of Sciences, Budapest, 2017; pp. $8-9$.

[8] Széman Zs, Tróbert AM. Social innovation in elderly's long term care - MoPAct WP8.3. National Report, Hungary. [Szociális innováció a tartós idősgondozásban. MoPAct WP 8.3. Nemzeti összefoglaló beszámoló, Magyarország.] Manuscript. Budapest, 2015; p. 44. [Hungarian]

[9] Tróbert AM. Supplementary brief analysis of the problems raised in the MoPAct WP8 T3 Hungarian focus group. [Kiegészítő elemzés a MoPAct WP8 T3 magyar fókuszcsoportjában felmerült problémafelvetéshez.] Manuscript. Budapest, 2016; pp. 4-5. [Hungarian]

[10] Kolozsvári LR, Rurik I. Quality improvement in primary care. Financial incentives related to quality indicators in Europe. [A minőség javításának lehetséges eszközei az alapellátásban. Minőségi indikátorokhoz kapcsolt anyagi ösztönzők Európában.] Orv Hetil. 2013; 154: 1096-1101. [Hungarian]

[11] Kolozsvári LR, Rurik I. Quality evaluation of primary care service performance. What are the problems with the recent Hungarian primary care indicators? [A háziorvosok teljesítményének minőségi értékelése. Mi a probléma a háziorvosi indikátorokkal?] Orv Hetil. 2016; 157: 328-335. [Hungarian]

[12] Varga I. Could quality assurance be considered as a new road in the social sphere? [Lehetséges-e a „minőségbiztosítás” a szociális szférában?] Kapocs 2008; 36. Available from: http://ncsszi.hu/ kiadvanyok/kapocs-letoltheto--lapszamai/kapocs-2008/86/ news [accessed: October 28, 2017]. [Hungarian]

[13] Szabó L. Elder care with question marks. [Idősellátás kérdőjelekkel.] Esély 2013; 24: 87-97. [Hungarian]

[14] Zrubka Zs. Measurement and health economic evaluation of informal care. [Az informális ellátás mérése és egészség-gazdaságtani értékelése.] Orv Hetil. 2017; 158: 1363-1372. [Hungarian]

(Tróbert Anett Mária, Budapest, Dési Huber u. 32. III/14., 1098 e-mail: trobert.maria@gmail.com) 